\title{
FIRST REDSCRIPTION AND A NEW HOST RECORD OF HYSTEROTHYLCIUM SEBAE BRUCE, 1990 FROM THE RED SEA FISH SCARUS PSITTACUS FROM EGYPT By
}

\author{
REFAAT M. A. KHALIFA ${ }^{1 *}$, HODA S. MOHAMADAIN ${ }^{2^{* *}}$ \\ and YASSER F. M. KARAR ${ }^{2}$
}

Department of Medical Parasitology, Faculty of Medicine, Assiut University ${ }^{1}$, and Department of Zoology, Faculty of Science, Qena, South Valley University ${ }^{2}$ Egypt ( ${ }^{\star}$ Correspondence: rkhalifa eg@yahoo.com, **hoda.abdelgalil@sci.svu.edu.eg)

\section{Abstract}

Hysterothylacium sebae Bruce, 1990 (Nematodea: Raphidascadae) was collected from the small intestine of the marine fish Scarus psicattatus caught from Northern Red Sea, of Sharm El-Naga, Makady Bay, Sothern Hurgada, Red Sea Governorate. Out of eight examined fish, three (37.5\%) were found naturally infected with $H$. sebae Bruce, 1990. The parasites (one adult male \& eight females) were examined morphologically and morphometrically by light microscopy. According to the previouse literature, the present nematode parasite was never redescribed or reported from the marine fish Scarus psicattus. Therefore, Scarus psittacus is reported as a new host record for Hysterothylacium sebae Bruce, 1990 and re-described in details for the first time from Egypt.

Keywords: Red Sea fishes, Nematoda, Raphidascadae, Hysterothylacium sebae, Scarus psittacus. New host record.

\section{Introduction}

Both adult and larvae of the genus Hysterothylacium Ward \& Magath, 1917 which were related to Anisakidae are commonly parasitizing marine, estuarine and freshwater fishes (Li. et al, 2008; 2013). Adult stages are restricted to the alimentary tract whilst, their larvae parasitize various tissues of numerous marine fishes (Machida et al, 1978; Machida, 1984) and invertebrates (Norris and Overstreet, 1976; Bruce et al, 1994). Balbuena et al. (2000) reported that infection by Hysterothylacium species caused clear economic repercussions due to its effect on the health of the fish hosts and even cause their death. In addition, species of this genus have been indicated as etiological agents of human intestinal anisakidosis (Yagi et al, 1996), due to provoking allergic reactions resultant from their somatic and excretion-secretion antigens (Valero et al, 2003).

Deardorff and Overstreet (1980) resurrected the genus Hysterothylacium to include species previously incorporated into both genera Thynnascaris Dollfus, 1933 and Contracaecum Railliet \& Henry, 1912. Bruce et al. (1994) reported 52 species in the genus Hysterothylacium while Li et al. (2007a, b) recorded over 60 species and clarified that the genus, together with Contracaecum Railliet \& Henry, 1912, is among the largest in the superfamily Ascaridoidea. Also, they presented a modified key to 63 Hysterothylacium species. Up to now more than 96 valid species of a wide distribution (Bezerra et al, 2018), however only two sets of unidentified Hysterothylacium larvae have been reported in fishes from Red Sea without any record of adult worms (Petter and Sey, 1997; Al-Zubaidy et al, 2012). Bruce and Cannon (1989) clarified that about $20 \%$ of the Hysterothylacium species were adequately described and more than $80 \%$ were in urgent need to be accurately re-described. Also, Bruce et al. (1994) and Moravec and Nagasawa (1998) referred to presence of many poorly described Hysterothylacium species which made any comparison with new forms very difficult and practically impossible. Moravec et al. (1985) suggested solving this dilemma through new nematode collections and their exact taxonomic evaluation.

The aim of the present work was to identify and re-describe encountered nematode Hysterothylacium sebae Bruce, 1990 in the Red Sea fishes. 


\section{Materials and Methods}

Fishes were transported alive as possible with good aeration and cooling immediately to the laboratory of Parasitology, Zoology Department, Faculty of Science, South Valley University at Qena Governorate, Egypt. Fishes were identified according to (Randall, 1982; Lieske and Myers, 1994, 1996; Lieske et al, 2004) and more confirmed through the fish base website (http://www.fishbase.org). The gastrointestinal tract was untangled with fingers (Justine et al, 2012). The whole digestive system and the remaining other viscera were opened longitudinally. Macroscopic and microscopic examination of different organs was carried out for detection of any visible helminth parasites. The collected parasites were cleaned by washing several times with isotonic saline solution. The relaxed nematodes were preserved in bottles containing mixture of $70 \%$ alcohol and 5\% glycerin. Coiled nematodes were transferred into warm $70 \%$ alcohol heated to $60^{\circ} \mathrm{C}$. The nematodes were mounted on slides with few drops of lactophenol and the parasite was covered by a cover slip. Identification of the encountered worms was done after the keys of the nematode parasites of vertebrates (Yorke et al, 1926; Anderson, 2000; Anderson et al, 2009).

\section{Results}

Incidence: Out of eight collected Scarus psittacus fishes (five males and three females); three; one male and two females (37.5\%) were found infected with nine adults Hysterothylacium sebae Bruce, 1990 in their small intestine; worm burden was 2 , 2,5 .

Description: Nine mature worms; one male and eight females were morphological studied (Fig. 1) and measurements, morphometric percentages and morphometric ratios were given (Tab. 1).

General: Live specimens were white while fixed ones were slightly yellowish brown. Small-sized nematodes without any transversely striated cuticle. Lateral alae inconspicuous, widest in region of first third of esophagus length; extend posteriorly to about middle level of ventricular appendix. Maximum width was at mid-body level and tapering to both extremities. Anterior extremity has three lips provided with broad lateral flanges; each lip has narrow base. Posterior part of dorsal lip rectangular, broad, with margins of lateral flanges almost parallel; anterior part of dorsal lip much narrower, anteriorly truncate with extremely tiny outcrops, separated from posterior part of lip by two fairly shallow lateral depressions. Amphids not observed. Interlabia somewhat developed. Muscular part of the esophagus is straight, cylindrical, long, slightly increasing in width posteriorly, ending in small ventriculus which is spherical to elongated oval, wider than or slightly as wide as esophagus (Fig. 1a). Ventricular appendix narrow, about half the esophagus length (Fig. 1b). Intestine brown was as wide as esophagus with thin and short intestinal cecum slightly longer than ventriculus and extended anteriorly on esophagus ventral side to about the end level its last fifth. Anterior deirids not observed. Nerve ring extended immediately transversely posterior to esophagus first third level by very small distance. Excretory pore just posterior to level of nerve-ring. Tail was conical with pointed tip horn-like \& with prominent large phasmids at the middle.

Male: Posterior end of body slightly ventrally arcuate, without caudal alae. Cloaca was represented by a small depressed region with small slit-like cloacal opening. Neither cloacl sucker nor muscular bands present anterior to cloaca. Papillae numerous, rounded, small and different sized, Phasmids large at middle of tail. Spicules were simple, alate, weakly chitinized, slender, similar in shape, equal in length, rounded anteriorly and tapering distally. No gubernaculum, tail conical, short, and wide. Tip blunt, rounded, without any caudal projection (Fig. $1 \mathrm{C} \& \mathrm{~F}$ ).

Female: Vulva equatorial. Vaginal opening not observed. Tail was conical, much longer and much wider than tail of male, 
with pointed tip horn-like and prominent

tions observed (Fig. 1, D\&E).

phasmids at the middle. No caudal projec-

Table 1: Measurements, morphometric percentages and morphometric ratios of Hysterothylacium seba.

\begin{tabular}{|c|c|c|}
\hline Measurements & Male & Female \\
\hline Body Length [L] & 10,227 & $7,667-10,085(8,876)$ \\
\hline Maximum body Width [W] & 140 & $125-182(154)$ \\
\hline Maximum body Width \%* & 1.4 & $1.6-1.8(1.7)$ \\
\hline lips length & 38 & $26-36(31)$ \\
\hline Esophagus length & 449 & $353-364(359)$ \\
\hline Esophagus length L\%* & 4.4 & $3.6-4.6(4.1)$ \\
\hline Esophagus width & 32 & $30-37(34)$ \\
\hline ventriculus length & 143 & $79-107(93)$ \\
\hline ventriculus length\%* & 1.4 & $0.8-1.4(1.1)$ \\
\hline ventriculus length: esophagus length ratio & $1: 3.14$ & $1: 3.30-4.61(1: 3.95)$ \\
\hline ventriculus width & 56 & $43-70(57)$ \\
\hline Ventricular appendix length & 145 & $149-195(172)$ \\
\hline Ventricular appendix length\%* & 1.4 & $1.5-2.5(2.0)$ \\
\hline Ventricular appendix width & 37 & $23-28(26)$ \\
\hline Intestinal cecum length & 184 & $94-116(105)$ \\
\hline Intestinal cecum length\%* & 1.8 & $0.9-1.5(1.2)$ \\
\hline Intestinal cecum length: ventricular appendix length ratio & $1: 0.79$ & $1: 1.59-1.68(1: 1.63)$ \\
\hline Intestinal cecum width & 28 & $22-27(25)$ \\
\hline Nerve ring L & 20 & $23-24(24)$ \\
\hline Nerve ring breadth & 72 & $50-59(55)$ \\
\hline Pre-Nerve ring distance & 211 & $171-210(191)$ \\
\hline Pre-Nerve ring distance $\% *$ & 2.1 & $2.1-2.2(2.2)$ \\
\hline Pre-excretory pore ring distance & 287 & $240-257(249)$ \\
\hline Pre-excretory pore ring distance $\% *$ & 2.8 & $2.5-3.1(2.8)$ \\
\hline Spicule length & 186 & Absent \\
\hline Spicule length\%* & 1.8 & - \\
\hline Rectum length & Absent & $49-103(76)$ \\
\hline Rectum length\%* & - & $0.6-1.0(0.8)$ \\
\hline Tail length & 157 & $133-156(145)$ \\
\hline Tail length\%* & 1.5 & $1.3-2.0(1.7)$ \\
\hline
\end{tabular}

All dimensions, measurements and $\%$ calculated to 1 decimal places; all ratios calculated to 2 decimal places. A\&B- Anterior extremity

\section{Discussion}

Yorke et al. (1926) gave place newly collected specimens in the superfamily Ascaridoidea Baird, 1853. Hartwich (1957); Fagerholm (1991); Nadler and Hudspeth (2000) indicated that they belong to the subfamily Raphidascaridinae Hartwich, 1954. The overall morphological appearance of the present specimens, particularly the structure of the cephalic end, excretory pore situated posterior to nerve ring level directly, and presence of both the intestinal caeca and the ventricular appendix, reveal obviously that present specimens belong to the genus Hysterothylacium Ward \& Magath, 1917 (Li et $a l, 2007 a)$. Since lateral alae were incon- spicuous and spicules about $1.8 \%$ of body length that gave an evidence that present specimens is $H$. sebae Bruce, 1990 (Li et al, 2007b) who related the genus as a member of Anisakidae.

These nematodes used fishes as intermediate and definitive hosts (Costa, 2004) (Fig. 1a). where adult nematodes of the genus Hysterothylacium Ward \& Magath, 1917 are generally restricted to the digestive tract of fishes (Machida, 1978), whilst their larval stages parasitize various tissues of numerous fishes and invertebrates (Norris and Overstreet, 1976). Deardorff and Overstreet (1981) presented the most detailed review of the genus Hysterothylacium. They resurrect- 
ed to include members of the genus Thynnascaris Dollfus, 1933 and others attributed to the genus Contracaecum Railliet \& Henry, 1912 that mature in fishes. Bruce et al. (1994), recorded 52 species inside Hysterothylacium. Li et al. (2007a;b) recorded over 60 species and clarified that the genus, together with Contracaecum Railliet \& Henry, 1912, was among the largest in the superfamily Ascaridoidea. They gave a modified key to 63 species in the genus Hysterothylacium. The present authors are in doubt about the validity of most of the reported species as differentiating criteria seem to be not sharp and evident (as relative length of spicules to that of the body) and it is recommended to make re-evaluation of the previously described species particularly those reported from the freshwater fishes and frogs (Raffel and Anderson, 2009).

The most recent taxonomic position of this genus showed more than 96 valid species of wide distribution (Bezerra et al, 2018). Only two sets of Hysterothylacium larvae were reported from the Red Sea region without recording their adult worms; Hysterothylacium KB found in Mene maculate, Mulloidichthys auriflamma, Otolithes argenteus, Pseudorhombus arsius, Sphyraena obtusata, and Upeneus sulphureus from Arabian Gulf, Kuwait by Petter and Say (1997) and records of Hysterothylacium sp. by Al-Zubaidy et al. (2012) parasitizing Epinephelus guttatus, Epinephelus tauvina, Sphyraena barracuda, Sphyraena jello, Lutjanus gibbus, Pristipomoides filamentosus, Abalistes stellaris and C. bajad from Yemen coasts. Al-Bassel (2006) re-described the adults and larval stages of Hysterothylacium winteri Torres \& Soto, 2004 from the marine fish Boops boops (Sparidae) from Alexandria fish market in Egypt. Hence, the present study presented the first re-description of Hysterothylacium sebae Bruce, 1990 from Egyptian Red Sea fish.

Only two parasites were previously reported from Scarus psittacus; a copepod Caligus callyodoni Prabha \& Pillai, 1986 (Lin and
Ho, 2004) and acanthocephalan species $\mathrm{Ne}$ oechinorhynchus ningaooensis (Pi-chelin and Cribb, 2001), hence Scarus psittacus herein is reported as a new host record of the nematode parasite Hysterothylacium sebae Bruce, 1990.

\section{Conclusion}

Hysterothylacium sebae Bruce, 1990 was re-described for the first time from the Red Sea fishes caught at Hurghada, Red Sea Governorate with addition of many in-ternal morphological and morphometrical features. The marine fish Scarus psittacus represented a new host record.

\section{References}

Al-Bassel, DA, 2006: Surface topography of Hysterothylacium winteri Torres and Soto, 2004 (Nematoda: Anisakidae) from Boops boops marine fishes from Egypt. Egypt. J. Aquat. Biol. Fish, 10, 1:125-38.

Al-Zubaidy, AB, Mhaisen, FT, Abker, MA M, 2012: Occurrence of five nematode species from some Red Sea fishes, Yemen. Mesopotamian J. Marine Sci. 27:140-56.

Anderson, RC, 2000: Nematode Parasites of Vertebrates: Development and Transmission. CABI, London.

Anderson, RC, Chabaud, AG, Willmott, S, 2009: Keys to the Nematode Parasites of Vertebrates: Arch. Vol. (Eds.). CABI, London.

Balbuena, JA, Karlsbakk, E, Kvenseth, A M, Saksvik, M, Nylund, A, 2000: Growth and emigration of third-stage larvae of Hysterothylacium aduncum (Nematoda: Anisakidae) in larval herring Clupea harengus. J. Parasitol. 86, 6:1271-5.

Bezerra, TN, Decraemer, W, Eisendle-Flöckner, U, et al, 2018: Nemys: World Database of Nematodes. Hysterothylacium Ward \& Magath, 1917: Accessed through: World Register of Marine Species. http://www.marinespecies. org/aphia.php? $\mathrm{p}=$ taxdetails\&id=1996 2 .

Bruce, NL, Cannon, LRG, 1989: Hysterothylacium, Iheringascaris and Maricostula new genus, nematodes (Ascaridoidea) from Australian pelagic marine fishes. J. Nat. Hist. 23: 1397-441.

Bruce, NL, Adlard, RD, Cannon, LRG, 1994: Synoptic checklist of ascaridoid parasites (Nematoda) from fish hosts. Invert. Taxonomy 8:583674.

Costa, G, Madeira, A, Pontes, T, D'Amélio, S, 
2004: Anisakid nematodes of the blackspot seabream, Pagellus bogaraveo, from Madeiran waters, Portugal. Acta Parasitol. 49:156-61.

Deardorff, TL, Overstreet, RM, 1980: Review of Hysterothylacium, and Iheringascaris (both previously=Thynnascaris) (Nematoda: Anisakidae) from the northern Gulf of Mexico. Proceed. Biol. Soc. Washington, 93:1035-79.

Fagerholm, HP, 1991: Systematic implications of male caudal morphology in ascaridoid nematode parasites. Syst. Parasitol. 19, 3:215-29.

Hartwich, G, 1957: On the systematics of the nematode superfamily Ascaridoidea. ZoologischeJahrbücher. Abteilung für Systematic, Ökologie und Geographie der Tiere 85:211-52.

Li, L, An, RY, Zhang, LP, 2007a: A new species of Hysterothylacium (Nematoda: Anisakidae) from marine fishes from Yellow Sea, China, with a key to the species of the genus Hysterothylacium. Zootaxa 1614:43-52.

Li, L, Xu, Z, Zhang, L, 2007b: A new species of genus Hysterothylacium Ward et Magath, 1917 (Nematoda, Anisakidae) from Lipa-ris tanakae (Scorpaeniformes, Liparidae) from the Yellow Sea, China. Acta Parasitol. 52, 4:371-5.

Li, L, Xu, Z, Zhang, L, 2008: Redescription of three species of Hysterothylacium (Nematoda: Anisakidae) from marine fishes from the Yellow Sea, China, with the synonymy of $\mathrm{Hy}$ sterothylacium muraenesoxin (Luo, 1999). Zootaxa 1878:55-67.

Li, L, Zhang, LP, Liu, YY, 2013: Hysterothylacium simile $\mathrm{n}$. sp. and $H$. aduncum (Rudolphi, 1802) (Nematoda: Raphidascarididae) from marine fishes in the Bohai and Yellow Sea, China, with comments on the record of $H$. paralichthydis (Yamaguti, 1941) from Chinese waters. Syst. Parasitol. 84, 1:57-69.

Lieske, E, Myers, RF, 1994: Collins Pocket Guide. Coral reef fishes: Caribbean, Indian Ocean, and Pacific Ocean including the Red Sea. Harper Collins, London.

Lieske, E, Fiedler, KE, Myers, RF, 2004: Coral Reef Guide: Red Sea to Gulf of Aden, South Oman: (Definitive Guide to Over 1200 species of Underwater Life). Harper Collins, London.

Lieske, E, Myers, RF, 1996: Coral Reef Fishes: Caribbean, Indian Ocean and Pacific Ocean Including the Red Sea (Vol. 41). Princeton, NJ: Princeton University Press.

Lin, CL, Ho, JS, 2004: Four of unrecorded caliged copepods parasitic in murine fishes of Taiwan. J. Fish. Soc. Taiwan, 2, 3:201-24.
Machida, M, 1984: Two new trematodes from tropical marine fishes of southwestern Japan. Bull. Nat. Sci. Mus. Tokyo, Ser. A, Zool. 10: 515.

Machida, M, Takahashi, K, Masuuchi, S, 1978: Thynnascaris haze n. sp. (Nematoda, Anisakidae) from goby in the Bay of Tokyo. Bull. Nat. Sci. Mus., Ser. A, Zool. 4:241-4.

Moravec, F, Nagasawa, K, Urawa, S, 1985: Some fish nematodes from fresh waters in Hokkaido, Japan. Folia Parasitol. 32:305-16.

Moravec, F, Nagasawa, K, 1998: Hysterothylacium japonicum sp. n. (Nematoda: Anisakidae) from the rare marine fish Trachipterus ishikawai in Japan. Acta Parasitol. 43:39-42.

Nadler, SA, Hudspeth, DS, 2000: Phylogeny of the Ascaridoidea (Nematoda: Ascaridida) based on three genes and morphology: hypotheses of structural and sequence evolution. J. Parasitol. 86, 2:380-93.

Norris DE, Overstreet RM, 1976: The public health implications of larval Thynnascaris nematodes from shellfish. Milk Food Technol. 39:4754.

Petter, AJ, Sey, O, 1997: Nematode parasites of marine fishes from Kuwait, with a description of Cucullanus trachinoti n. sp. from Tra-chinotus blochi. Zoosystema 19:35-59.

Pichelin, S, Cribb, TH, 2001: Neoechinorhynchus ningalooensis sp. nov. (Acanthocephala: Neoechinorhynchidae) from Scarus ghobban and S. psittacus (Scaridae) from Western Australia. Trans. Roy. Soc. South Australia 125, 1:51-5.

Prabha, C, Pillai, NK, 1986: Additions to the Copepods Parasitic on the Marine Fishes of India: On Twenty-Six Caligids Species (Vol. 4): Zoological Survey of India.

Raffel, TR, Anderson, TK, 2009: A new species of Hysterothylacium (Nematoda: Anisakidae) from the stomach of the red-spotted new, Notophthalmus viridescens from Pennnsylvania fishless ponds. J. Parasitol. 95, 6: 1503-6.

Randall, JE, 1982: The Diver's Guide to Red Sea Reef Fishes. Biblios Pub Distribution Service.

Valero, A, Terrados, S, Díaz, V, Reguera, V, Lozano, J, 2003: Determination of IgE in the serum of patients with allergic reactions to four species of fish-parasite anisakids. J. Invest. Allergol. Clin. Immunol. 13, 2:94-8.

Yagi, K, Nagasawa, K, Ishikura, H, Nagagawa, A, Sato, N, et al, 1996: Female worm Hys- 
terothylacium aduncum excreted from human: A case report. Japn. J. Parasitol. 45:12-23
Yorke, W, Maplestone, PA, Stiles, CW, 1926: The Nematode Parasites of Vertebrates. Hafner Publishing Company, New York.

\section{Explanation of figures}

Fig 1: Camera Lucida drawings of adults $H$. setae:

A\&B- Anterior extremity of parasite showed muscular oesophagus portions and intestine. C- Enlarged anterior extremity showed projectedlips like structure. D. Ventrolateral view of male posterior extremity showed spicule and cloaca. E \& F. Lateral view female posterior extremity showed tail, anus, and rectum.

Abbreviations; IC, intestinal cecum; In, intestine; MO, muscular oesophagus; Ta, tail; Ve, ventriculus. Li, Lip. An, anus; Cl, cloaca; IC, intestinal cecum, rectum; Sp, spicule; Ta, tail; Ve, ventriculu.

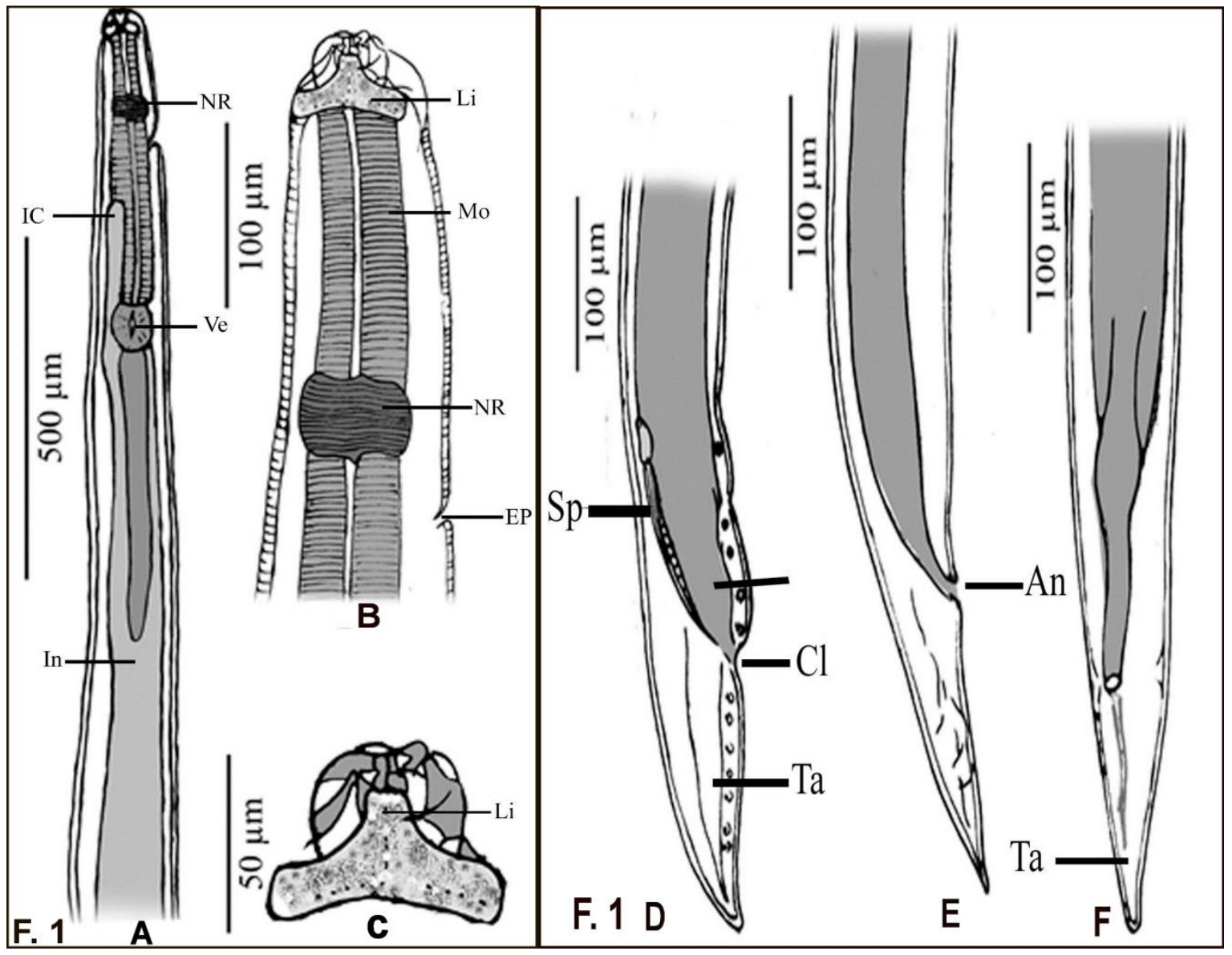

